\title{
Jarduera fisikoaren, obesitatearen eta ezaugarri soziodemografikoen arteko erlazioa unibertsitateko langileetan
}

\author{
(Interrelationship between physical activity, obesity and \\ sociodemographic characteristics among university workers)
}

Itxazne Garcia-Ceciaga ${ }^{1,3}$, Ana María Valle ${ }^{2}$ Inmaculada Arostegui ${ }^{2}$,
Jaime Zubero $^{4}$, Begoña Marina Jugo ${ }^{3}$,Elena Díaz-Ereño ${ }^{1 *}$

${ }^{1}$ Fisiologia Saila. Medikuntza eta Erizaintza Fakultatea. Euskal Herriko Unibertsitatea (UPV/EHU)

${ }^{2}$ Matematika Saila, Zientzia eta Teknologia Fakultatea, Euskal Herriko Unibertsitatea (UPV/EHU)

${ }^{3}$ Genetika, Antropologia Fisikoa eta Animalien Fisiologia. Zientzia eta Teknologia Fakultatea

Euskal Herriko Unibertsitatea (UPV/EHU)

${ }^{4}$ Erizaintza II Saila. Medikuntza eta Erizaintza Fakultatea.

Euskal Herriko Unibertsitatea (UPV/EHU)

\begin{abstract}
LABURPENA: Lan-ingurunean bizimodu osasungarriak sustatzea funtsezkoa da langileen osasuna eta autonomia ahalik eta ondoen mantentzeko. Gero eta interes handiagoa dago gehiegizko pisuaren, obesitatearen eta ohitura osasungarrien arteko erlazioa aztertzeko, bai eta jarduera fisikoa edo loaren iraupena eta kalitatea, lanaldiarekiko elkarreraginetan aztertzeko ere. Hala ere, ikerketa gutxik aztertu dituzte elkarreragin horiek unibertsitateko langileen artean. Helburua: Gainpisuaren prebalentzia tasa eta Jarduera Fisikoaren Nazioarteko Gomendioen betetze-maila estimatzea, eta, aldi berean, parametro horien eta faktore soziodemografikoen arteko loturak aztertzea izan dira helburuak. Metodoak: Unibertsitateko 292 langileren datuak bildu ziren, lan-osasuneko azterketan. Aldagai prediktibo eta emaitza bakoitzaren arteko erlazioak aztertzeko khi karratuaren edo Fisher-en proba zehatzak erabili ziren eta hari lotutako ezaugarrien ebaluaziorako aldagai anitzeko ereduak. Emaitzak: gehiegizko pisuaren prebalentzia \% 42koa izan zen. Sexuka, 35 eta 54 urte bitarteko gizonek eta $\geq 55$ urteko emakumeek II. mailako gehiegizko pisua edo obesitatea izateko arrisku handiagoa izan zuten. Jarduera Fisikoaren Nazioarteko Gomendioekiko atxikimendua \% 89koa izan zen, eta 7 ordu / egun baino gutxiago lo egiteak atxikimendua betetzeko probabilitatea handitu egin zuen. Ondorioak: Gehiegizko pisuaren prebalentzia adin ertaineko langileengan areagotu egiten da, eta gizonetan emakumeetan baino lehenago agertzen da. Gainera, loa eta jarduera fisikoa elkarreraginean egon daitezke.
\end{abstract}

HITZ GAKOAK: Jarduera fisikoa, GMI, langileak, gehiegizko pisua, obesitatea, loaldiaren iraupena.

ABSTRACT: The promotion of healthy lifestyles in the workplace is essential for the best maintenance of the health and autonomy of workers. There is an increasing interest in studying the relationship between overweight and obesity and healthy habits, such as physical activity (PA) or sleep duration and quality, in interactions with the work period. However, few studies have examined these interactions in university workers. Objective: To report the prevalence of overweight and the fulfilment of International Physical Activity Recommendations (PAR). To analyze the associations between PAR, body mass index and sociodemographic factors. Methods: Data from 292 university workers were collected during work health examinations. Chi-square or Fisher's exact tests used to assess relationships between each predictor and each outcome, and multivariate models to associated characteristics. Results: The prevalence of overweight was $42 \%$. Interestingly, men at 35-54 years old and women at $\geq 55$ years old presented greater risk of overweight grade II/obesity. The adherence to the PAR was $89 \%$ and sleep $<7$ hours/day increased the probability of fulfilling them. Conclusions: The prevalence of overweight increases in middle-aged workers, and earlier in men than in women, moreover, sleep-activity may be interacting with it.

KEYWORDS: Physical activity, BMI, workers, overweight, obesity, sleep duration.

* Harremanetan jartzeko / Corresponding author: Elena Díaz-Ereño. Fisiologia Saila, Medikuntza eta Erizaintza Fakultatea, Euskal Herriko Unibertsitatea UPV/EHU. Sarriena auzoa, z/g (48940 Leioa, Bizkaia). - elena.diaz@ehu.eus - https://orcid. org/0000-0003-1921-0318

Nola aipatu / How to cite: Garcia-Ceciaga, Itxazne; Valle, Ana María; Arostegui, Inmaculada; Zubero, Jaime; Jugo, Begoña Marina; Díaz-Ereño, Elena (2022). «Jarduera fisikoaren, obesitatearen eta ezaugarri soziodemografikoen arteko erlazioa unibertsitateko langileetan». Ekaia, 42, 2022, 207-225. (https://doi.org/10.1387/ekaia.22947).

Jasotze-data: 2021, ekainak 29; Onartze-data: 2021, urriak 7.

ISSN 0214-9001 - elSSN 2444-3255 / (c) 2022 UPV/EHU

(i) $(-)$ Lan hau Creative Commons Aitortu-EzKomertziala-LanEratorririkGabe 4.0 Nazioartekoa lizentzia baten mende dago 
Itxazne Garcia-Ceciaga, Ana María Valle, Inmaculada Arostegui, Jaime Zubero, Begoña Marina Jugo, Elena Díaz-Ereño

\section{SARRERA}

Lan-ingurunean bizimodu osasungarria sustatzea funtsezkoa da lan-bizitza osoan zehar osasuna eta norbanakoaren autonomia mantentzeko. Horretarako, lagungarria da ondo ulertzea osasuna zaintzeari lotutako taldeportaeraren eta ingurumen-faktoreen eragina.

Gero eta interes handiagoa dago gehiegizko pisuaren, obesitatearen eta ohitura osasungarrien arteko erlazioak aztertzeko, bai eta jarduera fisikoak edo loaren iraupenak eta kalitateak lanaldiarekin duen eragina ere [1, 2]. Gainera, lantokia ingurune egokia da osasuna babesteko faktoreak indartzeko eta arriskuak murrizteko: adibidez, gaixotasun ez-transmitigarrien (GET) garapena moteltzen edo saihesten dituzten esku-hartze programak. WHO Global Plan of Action on Workers' Health 2008-2017 [3] planak helburu argiak eta ekintzarako lehentasun-arloak ezartzen ditu, hala nola dieta osasungarria eta jarduera fisikoa.

Azken 25 urteetan, enpresa publiko eta pribatuek osasunaren kultura garatu dute prebentzio-zerbitzuen bidez. Langileen osasuna monitorizatu dute, eta lan-arrisku klasikoak eta emergenteak prebenitu, hala nola lesio muskular-eskeletikoak, GET edo laneko estresa. Lan-osasunari aplikatutako ikerketek langileen osasuna eta ohiturak deskribatzen dituzte, baita prebentzio estrategietarako diseinu hobeak ziurtatu ere $[4,5]$.

2004an eta aurreko urteetan ere OMEren Dietari, Jarduera Fisikoari eta Osasunari buruzko Estrategia Globalean islatu bezala, obesitatea mundumailako epidemia bihurtu da [6]. Munduko populazioaren \% 65 gehiegizko pisuagatik eta obesitateagatik pisu baxuagatik baino pertsona gehiago hiltzen diren herrialdeetan bizi da. Europan, gorputz-pisuaren arazoak azkar hazten ari dira; horrela, 2014. urtean, 18 urtetik gorako biztanleen \% 51,6k gehiegizko pisua zuela detektatu zen.

European Health Interview Survey (2014) inkestaren arabera, Espainian biztanleen $\% 52,6 \mathrm{k}$ gehiegizko pisua edo obesitatea du; Euskadin eragin txikiagoa du $(\% 46,4)$. Laneko arriskuen prebentzioan ikertzen duen Espainiako enpresa baten arabera (Premap Security and Health, 2015), Espainiako hainbat sektoretako langileen \% 54k OMEk gomendatutako GMIa (gorputz-masaren indizea) baino handiagoa zuen, nahiz eta Euskadik gainpisua duten langileen ehuneko txikiena izan (\% 35). Gainera, emakume langileek gizonezkoek baino gainpisu- eta loditasun-tasa txikiagoak izan zituzten, eta hori beste nazio-mailako lan batzuetan ere ikusi da [7, 8]. Langileen nutrizio-egoera ebaluatu duten ikerlanetan, erlazioak ezarri dira gehiegizko pisuaren, obesitatearen eta lanorduen artean [9], jarduera fisikoaren eta loaren iraupenaren artean [1], bai eta lan-produktibitatearen [10] eta faktore biologiko eta soziodemografikoen artean ere [11]. 
Ondo dokumentatuta dago jarduera fisiko erregularra eta egokia egiteak onura handiak dakarzkiola osasunari, eta hala, murriztu egiten dira diabetesa, hipertentsioa, obesitatea, depresioa eta sistema muskular-eskeletikoaren arazoak [12-14]. Jarduera fisikorik eza da munduko heriotza-tasaren laugarren kausa nagusia, eta munduko heriotzen \% 6 eragiten du [15], Europan \% 10 [16]. Biztanleriaren jarduera ezari buruzko datuak izugarri hazi dira; OMEren arabera (2010), Europan 18 urtetik gorako helduen $\% 20$ eta \% 27 ez ziren behar bezain aktiboak. Oro har, herrialde garatuetan, gizonen $\% 26 \mathrm{k}$ eta emakumeen $\% 35 \mathrm{ek}$ ez dute behar adina jarduera fisiko egiten [17].

Europako Osasunari buruzko Elkarrizketen Inkesten (EHIS, 2014) arabera, Espainiako helduen \% 50ek baino gehiagok denbora librean ez-aktibotzat aitortu zuen bere burua. Euskal Autonomia Erkidegoan (EAE), Osasunari buruzko 2018ko Inkestaren arabera jarduera fisikoaren maila baxua edo ez-osasuntsua zutenen portzentajea $\% 23$,3koa zen; eta gabezia hau nabariagoa zen emakumeetan, gizonekin alderatzean (\% 26,5 vs. \% 19,9).

Obesitatearen eta gizona izatearen, adinez nagusiagoa izatearen $[18,19]$ edota sedentarioa izatearen arteko lotura [20] ezaguna den modura, lanordu asko betetzeak zein loaren iraupen laburrak ere asoziazioa erakutsi izan dute, adibidez [21].

Loari dagokionez, iraupen laburrak osasunean negatiboki eragiten duela ezaguna izanik [1], azpimarragarria da, halaber, azken urteotan loaren iraupena eta kalitatea, biak, txarrera joan direla. Murrizketa hori egoera sozioekonomikoan eta bizimoduan izandako aldaketekin lotu izan da maiz, eta, seguru asko, gizarteratze-denborak ere eragina du, eta horrek interesgarri egiten du lan-testuingurua edo asoziatutako eragile soziodemografikoak ere aztertzea. Beraz, loditasun-epidemia loaldiak laburtzeko joerarekin batera gertatu dira, eta gero eta nabarmenagoa da loaren iraupen laburra eta loaren kalitate txarra obesitatea garatzeko arrisku-faktore berriak $[9,22]$ direla.

Loaren iraupenaren eta GMIaren arteko erlazioa eztabaidagarria da oraindik. Dena den, adostasuna dago loaren murrizketak energia gehiago eskatzen duela. Litekeena da lo gutxi egiten dutenen artean batzuk fisikoki aktiboagoak izatea, denbora gehiago esna daudelako, eta gaizki lo egiten duten beste batzuek, berriz, energia gutxiago eta aktibatzeko gaitasun gutxiago izatea [2].

Testuinguru horretan, lan honen helburua da informazioa ematea gehiegizko pisuaren, obesitatearen eta populazio jarduera mailaren zein OMEren jarduera fisikoaren gomendioen betetze-mailari buruz. Halaber, GMIren, Jarduera Fisiokoaren gomendioen, eguneroko ohituren, lan-jardueraren eta aldagai biosoziodemografikoen arteko erlazioa aztertzea. 
Itxazne Garcia-Ceciaga, Ana María Valle, Inmaculada Arostegui, Jaime Zubero, Begoña Marina Jugo, Elena Díaz-Ereño

\section{METODOAK}

\subsection{Parte-hartzaileak}

Ikerketa 2010etik 2013ra bitarteko ikasturteetan egin zen; 20 eta 71 urte bitarteko 317 pertsona izan ziren, eta unibertsitateko ikerketa- eta irakaskuntza-langileek (IIP) eta administrazioko eta zerbitzuetako langileek (AZP) parte hartu zuten. Prebentzio Zerbitzuan, urteroko lan-osasun azterketa baino lehen, lankide bakoitzak gonbita eta dokumentazioa jaso zituen. Ondoren, sinatutako baimen informatua jasota, 292 lagunek hartu zuten parte: 140 gizonek (\% 48) eta 152 emakumek (\% 52). Inor ez zen kanporatu aldez aurreko patologiagatik edo tratamendu medikoagatik. Datu guztiak babestu egin ditugu, Datu Pertsonalak Babesteari buruzko abenduaren 13ko 15/1999 Lege Organikoaren 5. artikuluan xedatutakoaren arabera. Unibertsitateko Etika Batzordeak ikerketa hau onartu zuen (CEISH/39/2010/JUGO ORRANTIA).

\subsection{Datu-bilketa}

\subsubsection{Galdetegiak}

Aldagai soziodemografikoak eta lan-jardueraren datuak ikerlan honetako egileek diseinatutako galdetegi auto-administratu baten bidez jaso ziren, SUN proiektuko «Bizimodua eta dieta» izeneko galdetegian oinarrituta (www.unav.edu/departamento/prevención/introsun) eta gure laginera egokituta. Adinaz eta sexuaz gain, zenbait aldagai soziodemografiko ere jaso ziren: hezkuntza-maila, familia-ekologia, seme-alaben kopurua, etxean menpekotasuna duten pertsonak izatea, etxeko lanetarako kanpoko laguntza, etxeko lanen partekatzea, aisialdia eta loaren iraupena. Lau adin-talde ezarri ziren: gazteak (20-34 urte), heldu gazteak (35-44 urte), heldu ertainak (45-54 urte) eta heldu nagusiak (55-71 urte). Lan-jarduerari dagokionez, langile-kolektiboa (IIP eta AZP) eta lanaldia (ordu/aste) sailkatu ziren, hiru taldetan banatuta: murriztua $(35 \mathrm{~h})$, estandarra $(35-45 \mathrm{~h})$ eta zabaldua $(45 \mathrm{~h})$.

\subsubsection{Neurri antropometrikoak}

Gorputz-masa $(\mathrm{kg})$ eta altuera $(\mathrm{m})$ Laneko Prebentzio Zerbitzuko osasun langileek neurtu zituzten. GMI kalkulatu zen, eta Obesitatea Aztertzeko Espainiako Elkartearen arabera (SEEDO) [24], parte-hartzaileen GMIren balioak honela sailkatu ziren: pisu baxua $\left(18,5 \mathrm{~kg} / \mathrm{m}^{2}\right)$, pisu normala $\left(18,5-24,9 \mathrm{~kg} / \mathrm{m}^{2}\right)$, I. mailako gehiegizko pisua $\left(25-26,9 \mathrm{~kg} / \mathrm{m}^{2}\right)$, II. mailako gehiegizko pisua $\left(27-29,9 \mathrm{~kg} / \mathrm{m}^{2}\right)$ edo obesitatea $\left(\geq 30 \mathrm{~kg} / \mathrm{m}^{2}\right)$. Analisi estatistikorako, parte-hartzaileak hiru kategoriatan sailkatu ziren: 1) pisu normala eta pisu baxua, 2) I. mailako gehiegizko pisua, eta 3) II. mailako gehiegizko pisua eta obesitatea. 


\subsubsection{Jarduera fisikoaren ebaluazioa}

Parte-hartzaileek Nazioarteko Jarduera Fisikoaren galdetegiaren (IPAQ) forma laburra [25] bete zuten. Egindako jarduera fisikoko denboraren datuak, baliokide metaboliko (MET) bihurtu ziren [26], eta parte-hartzaileak hiru jarduera fisikoko mailatan sailkatu ziren, IPAQ galdetegiaren sailkapenarekin bat eginez: oso aktiboak (jarduera kementsua gutxienez 3 egun/ aste, eta gutxienez $1.500 \mathrm{MET} \cdot \mathrm{min} /$ aste edo beste konbinaketa batzuk, gutxienez 3.000 MET - min/aste), minimoki aktiboak (gutxienez $20 \mathrm{~min} /$ egun jarduera kementsua $3 \leq$ egunetan, edo gutxienez $30 \mathrm{~min} /$ egun beste intentsitatetan $5 \leq$ egunetan), ez-aktiboak (aurreko baldintzak betetzen ez dituztenak) [27]. Bi aldagaien arteko erlazioa aztertzeko, azken biak «Ez-aktibo edo minimoki aktibo» kategorian elkartu ziren, eta oso aktiboen taldea kategoria bereizi batean. Azkenik, jarduera fisiko egokia definitu zen, helduen osasunerako OMEren gomendioetan oinarrituta [28]: $\geq 150$ minutu/astean intentsitate ertainean egitea jarduera fisikoa edo $\geq 75$ minutu/astean intentsitate kementsuan jarduera fisikoa, edo bien konbinaketa. Jarduera fisiko desegokia OMEren munduko gomendioak ez betetzean onartu zen.

\subsection{Analisi estatistikoak}

Laginaren ezaugarriak, maiztasunak eta proportzioak erabiliz deskribatu ziren. Jarduera fisikoa, IPAQ galdetegiaren arabera neurtua eta OMEren gomendioekiko atxikimenduak ebaluatua, eta GMI aldagaitzat hartu ziren. Aldagai prediktibo bakoitzaren eta emaitza bakoitzaren arteko bi aldagaien arteko erlazioaren ebaluazioa egiteko, khi karratuaren edo Fisherren proba zehatza erabili zen, bidezkoa denaren arabera. Aldagai prediktiboak aldagai anitzeko ereduetan sartu ziren, baldin eta $p<0,25$ bazen, erregresio logistiko bitarra erabiliz OMEren gomendiorako eta IPAQerako, eta GMIrako erregresio logistiko anizkoitza erabili zen. Azken ereduan estatistikoki esanguratsuak ziren iragarleak utzi ziren. Gainera, aztertutako aldagai guztien eta generoaren arteko aldagai biko erlazioak ebaluatu ziren: iragarleak eta emaitzak. Erregresio logistikoaren ereduaren emaitzak honela aurkezten dira: odds ratioa (OR), ORren \% 95eko konfiantza-tarteak (KT \% 95) eta arrisku-gertaeren probabilitate zenbatetsiak. Ondorio guztiak estatistikoki esanguratsuak izan ziren $\alpha=0,05$ mailan. Analisi guztiak R 3.2.3 bertsioarekin egin ziren ( $\mathrm{R}$ development Core Team 2010).

\section{EMAITZAK}

\subsection{Laginaren ezaugarriak}

Laginaren ezaugarriak 1. taulan ageri dira. Sexuari dagokionez, nahiko orekatua izan zen, eta batez ere (\% 60) adin ertaineko langileek (>44 urte) 
Itxazne Garcia-Ceciaga, Ana María Valle, Inmaculada Arostegui, Jaime Zubero, Begoña Marina Jugo, Elena Díaz-Ereño

1.taula. Langileen ezaugarriak lagin osorako eta sexuaren arabera.

\begin{tabular}{|c|c|c|c|c|c|c|c|c|}
\hline & \multirow{2}{*}{ Ezaugarriak } & \multicolumn{2}{|c|}{$\begin{array}{l}\text { Lagin osoa } \\
\text { (292) }\end{array}$} & \multicolumn{2}{|c|}{$\begin{array}{l}\text { Emakume } \\
(152)\end{array}$} & \multicolumn{2}{|c|}{$\begin{array}{l}\text { Gizon } \\
(140)\end{array}$} & \multirow{2}{*}{$\mathrm{P} *$} \\
\hline & & $\mathrm{n}$ & $\%$ & $\mathrm{n}$ & $\%$ & $\mathrm{n}$ & $\%$ & \\
\hline $\begin{array}{c}\text { Adina } \\
\text { (urteak) }\end{array}$ & $\begin{array}{l}20-34 \\
35-44 \\
45-54 \\
55-71\end{array}$ & $\begin{array}{r}35 \\
81 \\
116 \\
60\end{array}$ & $\begin{array}{l}(12) \\
(28) \\
(40) \\
(20)\end{array}$ & $\begin{array}{l}27 \\
45 \\
60 \\
20\end{array}$ & $\begin{array}{l}(77) \\
(56) \\
(52) \\
(33)\end{array}$ & $\begin{array}{r}8 \\
36 \\
56 \\
40\end{array}$ & $\begin{array}{l}(23) \\
(44) \\
(48) \\
(67)\end{array}$ & 0,001 \\
\hline $\begin{array}{l}\text { Langile- } \\
\text { kolektiboa }\end{array}$ & $\begin{array}{l}\text { AZP } \\
\text { IIP }\end{array}$ & $\begin{array}{r}83 \\
209\end{array}$ & $\begin{array}{l}(28) \\
(72)\end{array}$ & $\begin{array}{l}55 \\
97\end{array}$ & $\begin{array}{l}(66) \\
(46)\end{array}$ & $\begin{array}{r}28 \\
112 \\
\end{array}$ & $\begin{array}{l}(34) \\
(54)\end{array}$ & $<0,01$ \\
\hline $\begin{array}{l}\text { Hezkuntza- } \\
\text { maila }\end{array}$ & $\begin{array}{l}\text { Doktoretza edo Masterra } \\
\text { Unibertsitate-titulua } \\
\text { LH edo gutxiago }\end{array}$ & $\begin{array}{r}189 \\
71 \\
31 \\
\end{array}$ & $\begin{array}{l}(65) \\
(24) \\
(11)\end{array}$ & $\begin{array}{l}92 \\
39 \\
20\end{array}$ & $\begin{array}{l}(49) \\
(55) \\
(65)\end{array}$ & $\begin{array}{l}97 \\
32 \\
11\end{array}$ & $\begin{array}{l}(51) \\
(45) \\
(35)\end{array}$ & EA \\
\hline $\begin{array}{l}\text { Lanaldia } \\
\text { (ordu/aste) }\end{array}$ & $\begin{array}{l}\text { Murriztua }(<35) \\
\text { Estandarra }(35-45) \\
\text { Zabaldua }(>45)\end{array}$ & $\begin{array}{r}44 \\
203 \\
36\end{array}$ & $\begin{array}{l}(15) \\
(72) \\
(13)\end{array}$ & $\begin{array}{r}24 \\
109 \\
12\end{array}$ & $\begin{array}{l}(55) \\
(54) \\
(33)\end{array}$ & $\begin{array}{l}20 \\
94 \\
24\end{array}$ & $\begin{array}{l}(45) \\
(46) \\
(67)\end{array}$ & EA \\
\hline $\begin{array}{l}\text { Familia-egitura } \\
\quad \text { (nukleoa) }\end{array}$ & $\begin{array}{l}\text { Bakarrik bizi } \\
2 \text { kide bizi } \\
\geq 3 \text { kide bizi }\end{array}$ & $\begin{array}{r}26 \\
82 \\
177\end{array}$ & $\begin{array}{r}(9) \\
(29) \\
(62)\end{array}$ & $\begin{array}{l}12 \\
52 \\
85\end{array}$ & $\begin{array}{l}(46) \\
(63) \\
(48)\end{array}$ & $\begin{array}{l}14 \\
30 \\
92\end{array}$ & $\begin{array}{l}(54) \\
(37) \\
(52)\end{array}$ & EA \\
\hline $\begin{array}{c}\text { Umeak } \\
\text { (kopurua) }\end{array}$ & $\begin{array}{l}=0 \\
=1 \text { ala } 2 \\
\geq 3\end{array}$ & $\begin{array}{r}111 \\
156 \\
23 \\
\end{array}$ & $\begin{array}{r}(38) \\
(54) \\
(8)\end{array}$ & $\begin{array}{r}64 \\
79 \\
8\end{array}$ & $\begin{array}{l}(58) \\
(51) \\
(35)\end{array}$ & $\begin{array}{l}47 \\
77 \\
15\end{array}$ & $\begin{array}{l}(42) \\
(49) \\
(65)\end{array}$ & EA \\
\hline $\begin{array}{l}\text { Mendekotasunen bat } \\
\text { duenik etxean }\end{array}$ & $\begin{array}{l}\text { Bai } \\
\mathrm{Ez}\end{array}$ & $\begin{array}{r}92 \\
198 \\
\end{array}$ & $\begin{array}{l}(32) \\
(68) \\
\end{array}$ & $\begin{array}{r}47 \\
103 \\
\end{array}$ & $\begin{array}{l}(51) \\
(52)\end{array}$ & $\begin{array}{l}45 \\
95\end{array}$ & $\begin{array}{l}(49) \\
(48) \\
\end{array}$ & EA \\
\hline $\begin{array}{c}\text { Kanpoko laguntza } \\
\text { etxean }\end{array}$ & $\begin{array}{l}\text { Bai } \\
\mathrm{Ez}\end{array}$ & $\begin{array}{l}125 \\
162\end{array}$ & $\begin{array}{l}(44) \\
(56)\end{array}$ & $\begin{array}{l}68 \\
80\end{array}$ & $\begin{array}{l}(54) \\
(49)\end{array}$ & $\begin{array}{l}57 \\
82\end{array}$ & $\begin{array}{l}(46) \\
(51)\end{array}$ & EA \\
\hline $\begin{array}{c}\text { Etxeko karga } \\
\text { partekatu }\end{array}$ & $\begin{array}{l}\text { Bai } \\
\text { Ez }\end{array}$ & $\begin{array}{r}242 \\
33\end{array}$ & $\begin{array}{l}(88) \\
(12)\end{array}$ & $\begin{array}{r}121 \\
22\end{array}$ & $\begin{array}{l}(50) \\
(67)\end{array}$ & $\begin{array}{r}121 \\
11\end{array}$ & $\begin{array}{l}(50) \\
(33)\end{array}$ & EA \\
\hline Aisialdia & $\begin{array}{l}\text { Bai } \\
\mathrm{Ez}\end{array}$ & $\begin{array}{r}270 \\
15\end{array}$ & $\begin{array}{r}(95) \\
(5)\end{array}$ & $\begin{array}{r}139 \\
8\end{array}$ & $\begin{array}{l}(51) \\
(53)\end{array}$ & $\begin{array}{r}131 \\
7\end{array}$ & $\begin{array}{l}(49) \\
(47)\end{array}$ & EA \\
\hline $\begin{array}{l}\text { Aisialdirako denbora } \\
\text { (ordu/aste) }\end{array}$ & $\begin{array}{l}<5 \\
5-10 \\
>10\end{array}$ & $\begin{array}{r}10 \\
20 \\
167\end{array}$ & $\begin{array}{r}(5) \\
(10) \\
(85)\end{array}$ & $\begin{array}{r}6 \\
13 \\
80\end{array}$ & $\begin{array}{l}(60) \\
(65) \\
(48)\end{array}$ & $\begin{array}{r}4 \\
7 \\
87\end{array}$ & $\begin{array}{l}(40) \\
(35) \\
(52)\end{array}$ & EA \\
\hline $\begin{array}{l}\text { Loaren iraupena } \\
\text { (ordu/egun) }\end{array}$ & $\begin{array}{l}>8 \\
7-8 \\
<7\end{array}$ & $\begin{array}{r}12 \\
144 \\
133\end{array}$ & $\begin{array}{r}(4) \\
(50) \\
(46)\end{array}$ & $\begin{array}{l}11 \\
72 \\
67 \\
\end{array}$ & $\begin{array}{l}(92) \\
(50) \\
(50)\end{array}$ & $\begin{array}{r}1 \\
72 \\
66\end{array}$ & $\begin{array}{r}(8) \\
(50) \\
(50)\end{array}$ & $<0,05$ \\
\hline Jarduera fisikoa & $\begin{array}{l}\text { Ez aktibo, gutxieneko aktiboa } \\
\text { Oso aktiboa }\end{array}$ & $\begin{array}{r}225 \\
67\end{array}$ & $\begin{array}{l}(77) \\
(23)\end{array}$ & $\begin{array}{r}122 \\
30\end{array}$ & $\begin{array}{l}(54) \\
(45)\end{array}$ & $\begin{array}{r}103 \\
37\end{array}$ & $\begin{array}{l}(46) \\
(55)\end{array}$ & EA \\
\hline $\begin{array}{l}\text { OMEren Jarduera } \\
\text { fisikoaren } \\
\text { gomendioak betetzea }\end{array}$ & $\begin{array}{l}\text { Bai (Egokia) } \\
\text { Ez (Ezegokia) }\end{array}$ & $\begin{array}{r}260 \\
32\end{array}$ & $\begin{array}{l}(89) \\
(11)\end{array}$ & $\begin{array}{r}135 \\
17\end{array}$ & $\begin{array}{l}(52) \\
(53)\end{array}$ & $\begin{array}{r}125 \\
15\end{array}$ & $\begin{array}{l}(48) \\
(47)\end{array}$ & \\
\hline GMI $\left(\mathrm{kg} / \mathrm{m}^{2}\right)$ & $\begin{array}{l}\text { Normala edo baxuegia } \\
\text { I mailako gainpisua } \\
\text { II mailako gainpisua/Obesitatea }\end{array}$ & $\begin{array}{r}169 \\
58 \\
65\end{array}$ & $\begin{array}{l}(58) \\
(20) \\
(22)\end{array}$ & $\begin{array}{r}110 \\
20 \\
22\end{array}$ & $\begin{array}{l}(65) \\
(34) \\
(34)\end{array}$ & $\begin{array}{l}59 \\
38 \\
43\end{array}$ & $\begin{array}{l}(35) \\
(66) \\
(66)\end{array}$ & $<0,001$ \\
\hline
\end{tabular}

AZP: Administrazio eta Zerbitzuen Pertsonala: IIP: Irakasleak eta Ikertzaileak; LH: Lanbide Heziketa.

* Khi-karratua edo Fisher-en testa erabili zen. 
osatu zuten. Erdiak baino gehiagok (\% 65ek) doktorego- edota master-ikasketak zituzten, gehienak IIPko kolektibokoak ziren (\% 72), eta lan-egun estandarra zuten (35-45 ordu astean). Langile gehienek, genero-desberdintasunik gabe, astean 10 ordu baino gehiago eman zuten aisialdian (\% 85). Ia guztiek adierazi zuten egunean 8 ordu edo gutxiago lo egiten zutela, eta ia erdiak egunero $<7$ ordu egiten zutela lo.

Sexuaren araberako aldeak esanguratsuak izan ziren adinari, lan taldeari, GMIari eta loaren iraupenari dagokionez. Emakumeen ehunekoa gizonena baino handiagoa izan zen adin gazteenaren taldean $(p=0,001)$; AZPko langileen taldean, IIPko langileekin alderatuta $(p<0,01)$; eta 8 ordu/egun baino gehiago lo egiten zutenen artean ere bai $(p<0,05)$.

Jarduera fisikoaren kuantifikazioari dagokionez (IPAQ), gehienak kategoria ez-aktibokoak edo aktibitate txikienekoak (\% 77) ziren, \% 23 baino ez ziren kategoria aktibokoak, eta ez zegoen gizonen eta emakumeen arteko alde nabarmenik. Hala ere, jarduera-maila horiekin, gehienek (\% 89) OMEk gomendatutako jarduera fisikoko gutxieneko maila bete zuten, sexuaren araberako alderik gabe. Gutxi gorabehera \% 42k gehiegizko pisua edo obesitatea zuen, eta bai I. mailako gehiegizko pisua- eta bai II. mailako gehiegizko pisua edo obesitatea zutenetan ere, gizonen proportzioa emakumeena baino handiagoa zen $(p<0,001)$.

\subsection{Aztertutako aldagaien arteko erlazioak}

Jarduera fisikoa (2. taula) ez zen modu esanguratsuan erlazionatu ezaugarri soziodemografikoekin. Hala ere, jarduera fisiko egokia (OME) erlazionatu zen $<7$ ordu / egun lo egitearekin $(p<0,01)$, nahiz eta beste ezaugarriak ez ziren modu esanguratsuan erlazionatu. Hiru kategoria$\tan (3$. taula) sailkatutako GMIarekin lortutako emaitzen arabera, gizonak nabarmen lotu ziren II. mailako gehiegizko pisuarekin edo obesitatearekin $(p<0,001)$, haren ehunekoa handiagoa baitzen gizonezkoetan (\% 31) emakumezkoetan baino (\% 15) $(p<0,001)$. Gainera, II. mailako gehiegizko pisua edo obesitatea izateko arriskua asko handitu zen adinak aurrera egin ahala $(p<0,001)$. Beste ezaugarri batzuk ez ziren erlazionatu. Hala ere, GMI bi kategoriatan sailkatu zenean (normala edo pisu baxukoa vs. gehiegizko pisua edo obesitatea), loaren iraupenarekin lotu zen nabarmen $(p=0,021)$, eta lo-urritasuna zutenek ( $<7$ ordu/egun) $10,2$ [KT \% $95(1,3,81,2)]$ probabilitate handiagoa zuten gehiegizko pisua edo obesitatea izateko, egunean 8 ordu baino gehiago lo egiten zutenekin alderatuta. 
2. taula. Jarduera fisikoaren eta ezaugarri soziodemografiko zein bizi-ohituren arteko asoziazioa.

\begin{tabular}{|c|c|c|c|c|c|c|c|}
\hline \multirow{3}{*}{\multicolumn{2}{|c|}{ Ezaugarriak }} & \multicolumn{3}{|c|}{ Jarduera fisikoaren maila } & \multicolumn{3}{|c|}{ OMEren gomendioak betetzea } \\
\hline & & $\begin{array}{l}\text { Ez aktiboa } \\
\quad \text { edo } \\
\text { minimoki } \\
\text { aktiboa }\end{array}$ & $\begin{array}{l}\text { Oso } \\
\text { aktiboa }\end{array}$ & $\mathrm{P}^{*}$ & $\begin{array}{c}\mathrm{JF} \\
\text { egokia }\end{array}$ & $\begin{array}{c}\text { JF } \\
\text { ezegokia }\end{array}$ & $\mathrm{P}^{*}$ \\
\hline & & $225(\% 7)$ & $67(\% 23)$ & & $260(\% 89)$ & $32(\% 11)$ & \\
\hline Sexua & $\begin{array}{l}\text { Emakumea } \\
\text { Gizona }\end{array}$ & $\begin{array}{l}122(80) \\
103(74)\end{array}$ & $\begin{array}{l}30(20) \\
37(26)\end{array}$ & EA & $\begin{array}{l}135(89) \\
125(89)\end{array}$ & $\begin{array}{l}17(11) \\
15(11)\end{array}$ & EA \\
\hline $\begin{array}{l}\text { Adina } \\
\text { (urteak) }\end{array}$ & $\begin{array}{l}20-34 \\
35-44 \\
45-54 \\
55-71\end{array}$ & $\begin{array}{l}26(74) \\
61(75) \\
94(81) \\
44(73)\end{array}$ & $\begin{array}{r}9(26) \\
20(25) \\
22(19) \\
16(27)\end{array}$ & EA & $\begin{array}{r}33(94) \\
69(85) \\
103(89) \\
55(92)\end{array}$ & $\begin{array}{r}2(6) \\
12(15) \\
13(11) \\
5(8)\end{array}$ & EA \\
\hline $\begin{array}{l}\text { Langile- } \\
\text { kolektiboa }\end{array}$ & $\begin{array}{l}\text { AZP } \\
\text { IIP }\end{array}$ & $\begin{array}{r}64(77) \\
161(77)\end{array}$ & $\begin{array}{l}19(23) \\
48(23)\end{array}$ & EA & $\begin{array}{l}78(94 .) \\
182(87)\end{array}$ & $\begin{array}{r}5 \quad(6) \\
27(13)\end{array}$ & EA \\
\hline $\begin{array}{l}\text { Hezkuntza- } \\
\text { maila }\end{array}$ & $\begin{array}{l}\text { Doktoretza edo Masterra } \\
\text { Unibertsitate-titulua } \\
\text { LH edo gutxiago }\end{array}$ & $\begin{array}{r}150(79) \\
53(75) \\
21(68)\end{array}$ & $\begin{array}{l}39(21) \\
18(25) \\
10(32)\end{array}$ & EA & $\begin{array}{r}165(87) \\
64(90) \\
30(97)\end{array}$ & $\begin{array}{r}24(13) \\
7(10) \\
1 \quad(3)\end{array}$ & EA \\
\hline $\begin{array}{l}\text { Lanaldia } \\
\text { (ordu/aste) }\end{array}$ & $\begin{array}{l}\text { Murriztua }(<35) \\
\text { Estandarra }(35-45) \\
\text { Zabaldua }(>45)\end{array}$ & $\begin{array}{r}31(70) \\
160(79) \\
26(72)\end{array}$ & $\begin{array}{l}13(30) \\
43(21) \\
10(28)\end{array}$ & EA & $\begin{array}{r}40(91) \\
178(88) \\
33(92)\end{array}$ & $\begin{array}{rr}4 & (9) \\
25 & (12) \\
3 & (8)\end{array}$ & EA \\
\hline $\begin{array}{l}\text { Familia-egitura } \\
\quad \text { (nukleoa) }\end{array}$ & $\begin{array}{l}\text { Bakarrik bizi } \\
2 \text { kide bizi } \\
\geq 3 \text { kide bizi }\end{array}$ & $\begin{array}{r}19(73) \\
63(77) \\
137(77)\end{array}$ & $\begin{array}{r}7(27) \\
19(23) \\
40(23)\end{array}$ & EA & $\begin{array}{r}22(85) \\
71(87) \\
161(91)\end{array}$ & $\begin{array}{r}4(15) \\
11(13) \\
16(9)\end{array}$ & EA \\
\hline Umeak (kopurua) & $\begin{array}{l}=0 \\
=1 \text { ala } 2 \\
\geq 3\end{array}$ & $\begin{array}{r}80(72) \\
126(81) \\
17(74)\end{array}$ & $\begin{array}{r}31(28) \\
30(19) \\
6(26)\end{array}$ & EA & $\begin{array}{r}98(88) \\
139(89) \\
21(91)\end{array}$ & $\begin{array}{r}13(12) \\
17(11) \\
2 \quad(9)\end{array}$ & EA \\
\hline $\begin{array}{l}\text { Mendekotasunen } \\
\text { bat duenik etxean }\end{array}$ & $\begin{array}{l}\text { Bai } \\
\mathrm{Ez}\end{array}$ & $\begin{array}{r}72(78) \\
151(76)\end{array}$ & $\begin{array}{l}20(22) \\
47(24)\end{array}$ & EA & $\begin{array}{r}81(88) \\
177(89)\end{array}$ & $\begin{array}{l}11(12) \\
21(11)\end{array}$ & EA \\
\hline $\begin{array}{c}\text { Kanpoko } \\
\text { laguntza etxean }\end{array}$ & $\begin{array}{l}\text { Bai } \\
\mathrm{Ez}\end{array}$ & $\begin{array}{l}101(81) \\
120(74)\end{array}$ & $\begin{array}{l}24(19) \\
42(26)\end{array}$ & EA & $\begin{array}{l}108(86) \\
148(91)\end{array}$ & $\begin{array}{l}17(14) \\
14 \quad(9)\end{array}$ & EA \\
\hline $\begin{array}{c}\text { Etxeko karga } \\
\text { partekatu }\end{array}$ & $\begin{array}{l}\text { Bai } \\
\mathrm{Ez}\end{array}$ & $\begin{array}{r}188(78) \\
25(76)\end{array}$ & $\begin{array}{r}54(22) \\
8(24)\end{array}$ & EA & $\begin{array}{r}214(88) \\
31(94)\end{array}$ & $\begin{array}{r}28(12) \\
2 \quad(6)\end{array}$ & \\
\hline Aisialdia & $\begin{array}{l}\text { Bai } \\
\mathrm{Ez}\end{array}$ & $\begin{array}{r}206(76) \\
14(93)\end{array}$ & $\begin{array}{r}64(24) \\
1 \quad(7)\end{array}$ & EA & $\begin{array}{r}241(89) \\
13(87)\end{array}$ & $\begin{array}{r}29(11) \\
2(13)\end{array}$ & EA \\
\hline $\begin{array}{c}\text { Aisialdirako } \\
\text { denbora } \\
\text { (ordu/aste) }\end{array}$ & $\begin{array}{l}<5 \\
5-10 \\
>10\end{array}$ & $\begin{array}{r}8(80) \\
14(70) \\
124(74)\end{array}$ & $\begin{array}{r}2(20) \\
6(30) \\
43(26)\end{array}$ & EA & $\begin{array}{r}8(80) \\
17(85) \\
153(92)\end{array}$ & $\begin{array}{r}2(20) \\
3(15) \\
14 \quad(8)\end{array}$ & EA \\
\hline $\begin{array}{l}\text { Loaren iraupena } \\
\text { (ordu/egun) }\end{array}$ & $\begin{array}{l}>8 \\
7-8 \\
<7\end{array}$ & $\begin{array}{r}11(92) \\
117(81) \\
95(71)\end{array}$ & $\begin{array}{r}1(8) \\
27(19) \\
38(29)\end{array}$ & EA & $\begin{array}{r}8(67) \\
124(86) \\
125(94)\end{array}$ & $\begin{array}{r}4(33) \\
20(14) \\
8 \quad(6)\end{array}$ & $<0,01$ \\
\hline
\end{tabular}

JF: Jarduera Fisikoa; AZP: Administrazio eta Zerbitzuen Pertsonala: IIP: Irakasleak eta Ikertzaileak; LH: Lanbide Heziketa.

* Khi-karratua edo Fisher-en testa erabili zen. 
3. taula. GMIaren eta aldagai soziodemografiko zein bizi-ohituren arteko asoziazioa.

\begin{tabular}{|c|c|c|c|c|c|}
\hline & \multirow{3}{*}{ Ezaugarriak } & \multicolumn{3}{|c|}{ Fenotipoa GMIren arabera $\left(\mathrm{kg} / \mathrm{m}^{2}\right)$} & \multirow[b]{2}{*}{$\mathrm{P}^{*}$} \\
\hline & & $\begin{array}{l}\text { Normal } \\
\text { edo } \\
\text { gutxiegi }\end{array}$ & $\begin{array}{l}\text { I mailako } \\
\text { Gainpisua }\end{array}$ & $\begin{array}{l}\text { II mailako } \\
\text { Gainpisua edo } \\
\text { Obesitatea }\end{array}$ & \\
\hline & & $169(\% 58)$ & $58(\% 20)$ & $65(\% 22)$ & \\
\hline Sexua & $\begin{array}{l}\text { Emakumea } \\
\text { Gizona }\end{array}$ & $\begin{array}{r}110(72) \\
59(42)\end{array}$ & $\begin{array}{l}20(13) \\
38(27)\end{array}$ & $\begin{array}{l}22(15) \\
43(31)\end{array}$ & $<0,001$ \\
\hline $\begin{array}{c}\text { Adina } \\
\text { (urteak) }\end{array}$ & $\begin{array}{l}20-34 \\
35-44 \\
45-54 \\
55-71\end{array}$ & $\begin{array}{l}26(74) \\
59(73) \\
64(55) \\
20(33)\end{array}$ & $\begin{array}{r}5(14) \\
12(15) \\
24(21) \\
17(28)\end{array}$ & $\begin{array}{r}4(11) \\
10(12) \\
28(24) \\
23(38)\end{array}$ & $<0,001$ \\
\hline Langile-kolektiboa & $\begin{array}{l}\text { AZP } \\
\text { IIP }\end{array}$ & $\begin{array}{r}50(60) \\
119(57)\end{array}$ & $\begin{array}{l}14(17) \\
44(21)\end{array}$ & $\begin{array}{l}19(23) \\
46(22)\end{array}$ & EA \\
\hline Hezkuntza-maila & $\begin{array}{l}\text { Doktoretza edo Masterra } \\
\text { Unibertsitate-titulua } \\
\text { LH edo gutxiago }\end{array}$ & $\begin{array}{r}110(58) \\
39(55) \\
19(61)\end{array}$ & $\begin{array}{r}41(22) \\
12(17) \\
5(16)\end{array}$ & $\begin{array}{r}38(20) \\
20(28) \\
7(23)\end{array}$ & EA \\
\hline $\begin{array}{l}\text { Lanaldia } \\
\text { (ordu/aste) }\end{array}$ & $\begin{array}{l}\text { Murriztua }(<35) \\
\text { Estandarra }(35-45) \\
\text { Zabaldua }(>45)\end{array}$ & $\begin{array}{r}22(50) \\
126(62) \\
16(44)\end{array}$ & $\begin{array}{r}9(20) \\
38(19) \\
9(25)\end{array}$ & $\begin{array}{l}13(30) \\
39(19) \\
11(31)\end{array}$ & EA \\
\hline $\begin{array}{l}\text { Familia-egitura } \\
\quad \text { (nukleoa) }\end{array}$ & $\begin{array}{l}\text { Bakarrik bizi } \\
2 \text { kide bizi } \\
\geq 3 \text { kide bizi }\end{array}$ & $\begin{array}{r}15(58) \\
46(56) \\
103(58)\end{array}$ & $\begin{array}{r}4(15) \\
17(21) \\
35(20)\end{array}$ & $\begin{array}{r}7(27) \\
19(23) \\
39(22)\end{array}$ & EA \\
\hline $\begin{array}{c}\text { Umeak } \\
\text { (kopurua) }\end{array}$ & $\begin{array}{l}=0 \\
=1 \text { ala } 2 \\
\geq 3\end{array}$ & $\begin{array}{r}69(62) \\
89(57) \\
9(39)\end{array}$ & $\begin{array}{r}23(21) \\
30(19) \\
5(22)\end{array}$ & $\begin{array}{r}19(17) \\
37(24) \\
9(39)\end{array}$ & EA \\
\hline $\begin{array}{l}\text { Mendekotasunen bat } \\
\text { duenik etxean }\end{array}$ & $\begin{array}{l}\text { Bai } \\
\text { Ez }\end{array}$ & $\begin{array}{r}113(57) \\
54(59)\end{array}$ & $\begin{array}{l}42(21) \\
16(17)\end{array}$ & $\begin{array}{l}43(22) \\
22(24)\end{array}$ & EA \\
\hline $\begin{array}{c}\text { Kanpoko laguntza } \\
\text { etxean }\end{array}$ & $\begin{array}{l}\text { Bai } \\
\text { Ez }\end{array}$ & $\begin{array}{l}92(57) \\
74(59)\end{array}$ & $\begin{array}{l}31(19) \\
26(21)\end{array}$ & $\begin{array}{l}39(24) \\
25(20)\end{array}$ & EA \\
\hline $\begin{array}{c}\text { Etxeko karga } \\
\text { partekatu }\end{array}$ & $\begin{array}{l}\text { Bai } \\
\text { Ez }\end{array}$ & $\begin{array}{r}16(49) \\
143(59)\end{array}$ & $\begin{array}{r}5(15) \\
48(20)\end{array}$ & $\begin{array}{l}12(36) \\
51(21)\end{array}$ & EA \\
\hline Aisialdia & $\begin{array}{l}\text { Bai } \\
\text { Ez }\end{array}$ & $\begin{array}{r}11(74) \\
153(57)\end{array}$ & $\begin{array}{r}2(13) \\
55(20)\end{array}$ & $\begin{array}{r}2(13) \\
62(23)\end{array}$ & EA \\
\hline $\begin{array}{l}\text { Aisialdirako denbora } \\
\text { (ordu/aste) }\end{array}$ & $\begin{array}{l}<5 \\
5-10 \\
>10\end{array}$ & $\begin{array}{r}5(50) \\
15(75) \\
90(54)\end{array}$ & $\begin{array}{r}3(30) \\
3(15) \\
35(21)\end{array}$ & $\begin{array}{r}2(20) \\
2(10) \\
42(25)\end{array}$ & EA \\
\hline $\begin{array}{l}\text { Loaren iraupena } \\
\text { (ordu/egun) }\end{array}$ & $\begin{array}{l}>8 \\
7-8 \\
<7\end{array}$ & $\begin{array}{l}11(92) \\
86(60) \\
69(52)\end{array}$ & $\begin{array}{r}1(8) \\
26(18) \\
31(23)\end{array}$ & $\begin{array}{r}0(0,0) \\
32(22) \\
33(25)\end{array}$ & EA \\
\hline Jarduera fisikoa & $\begin{array}{l}\text { Ez aktibo, edo minimoki aktiboa } \\
\text { Oso aktiboa }\end{array}$ & $\begin{array}{r}129(57) \\
4060)\end{array}$ & $\begin{array}{l}43(19) \\
15(22)\end{array}$ & $\begin{array}{l}53(24) \\
12(18)\end{array}$ & EA \\
\hline $\begin{array}{c}\text { OMEren JFaren } \\
\text { gomendioak betetzea }\end{array}$ & $\begin{array}{l}\text { Bai (Egokia) } \\
\text { Ez (Ezegokia) }\end{array}$ & $\begin{array}{r}150(58) \\
19(59)\end{array}$ & $\begin{array}{r}51(19) \\
7(22)\end{array}$ & $\begin{array}{r}59(23) \\
6(19)\end{array}$ & EA \\
\hline
\end{tabular}

JF: Jarduera Fisikoa; AZP: Administrazio eta Zerbitzuen Pertsonala: IIP: Irakasleak eta Ikertzaileak; LH: Lanbide Heziketa.

* Khi-karratua edo Fisher-en testa erabili zen. 
Lo-orduen kopurua handitzeak OMEren jarduera fisikoaren gomendioei ez atxikitzeko arriskua handitu zuen $(p<0,01) .7$ ordu baino gutxiago lo egin zutenek jarduera fisiko egokia egiteko probabilitate handiagoa zuten $7-8$ ordu lo egin zutenekin alderatuta [KT \% $95(1,9,31,6)]$ (1. irudia). Eta azken horiek 8 ordu baino gehiago lo egiten zutenekin alderatzean, ez zen lotura esanguratsurik aurkitu. Loaren iraupenaren eta jarduera fisiko desegokiaren arteko erlazioa aztertzean adina eta generoa kontrolatzeko, biak gehitu zitzaizkion ereduari; hala ere, eredu osoak ez zuen adierazgarritasunik lortu.

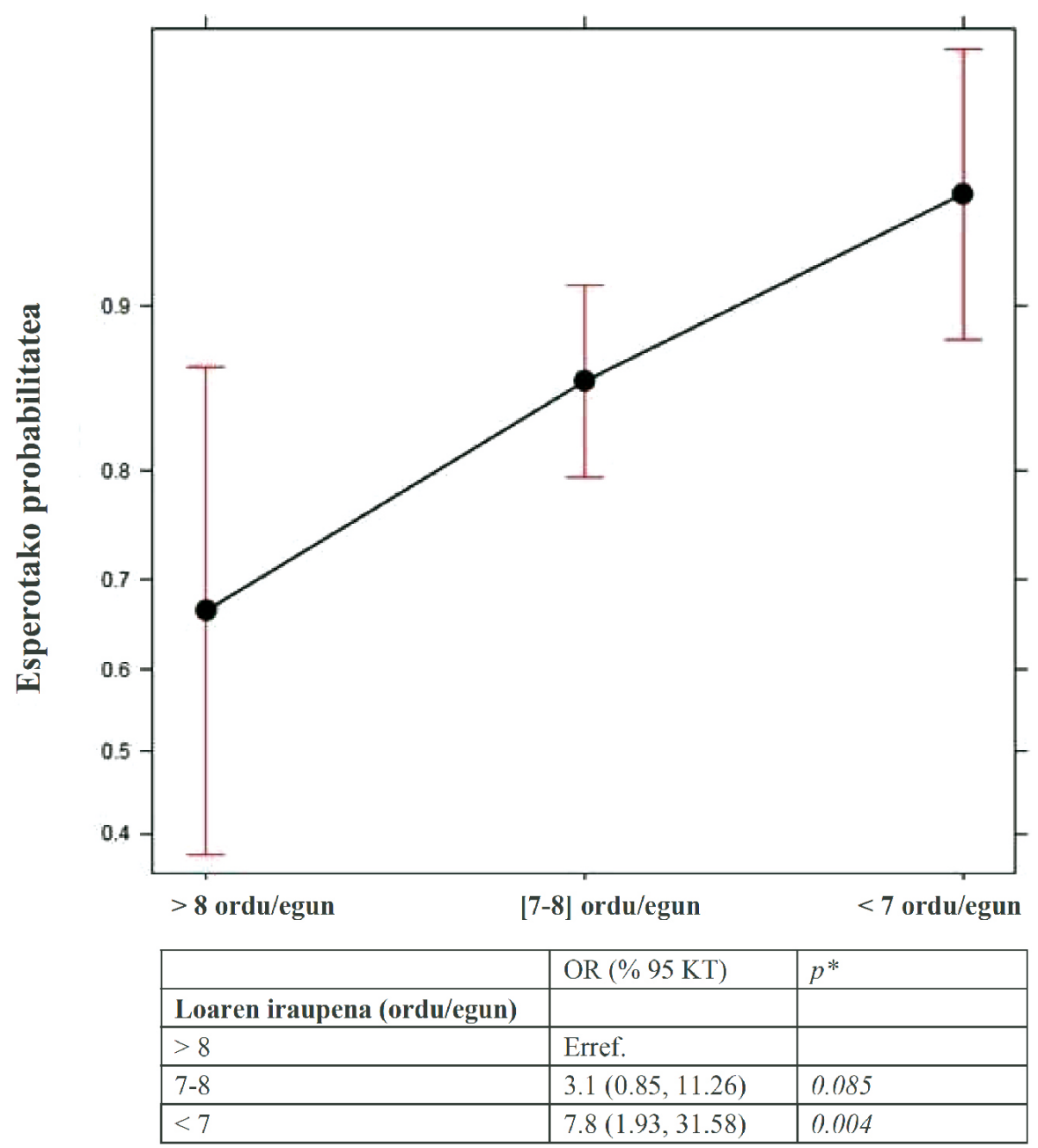

1. irudia. Jarduera fisikoaren Esperotako probabilitatea OMEren gomendioak betetzeko. Aldagai prediktiboa: loaren iraupena. * Wald-en testa erabili zen. 


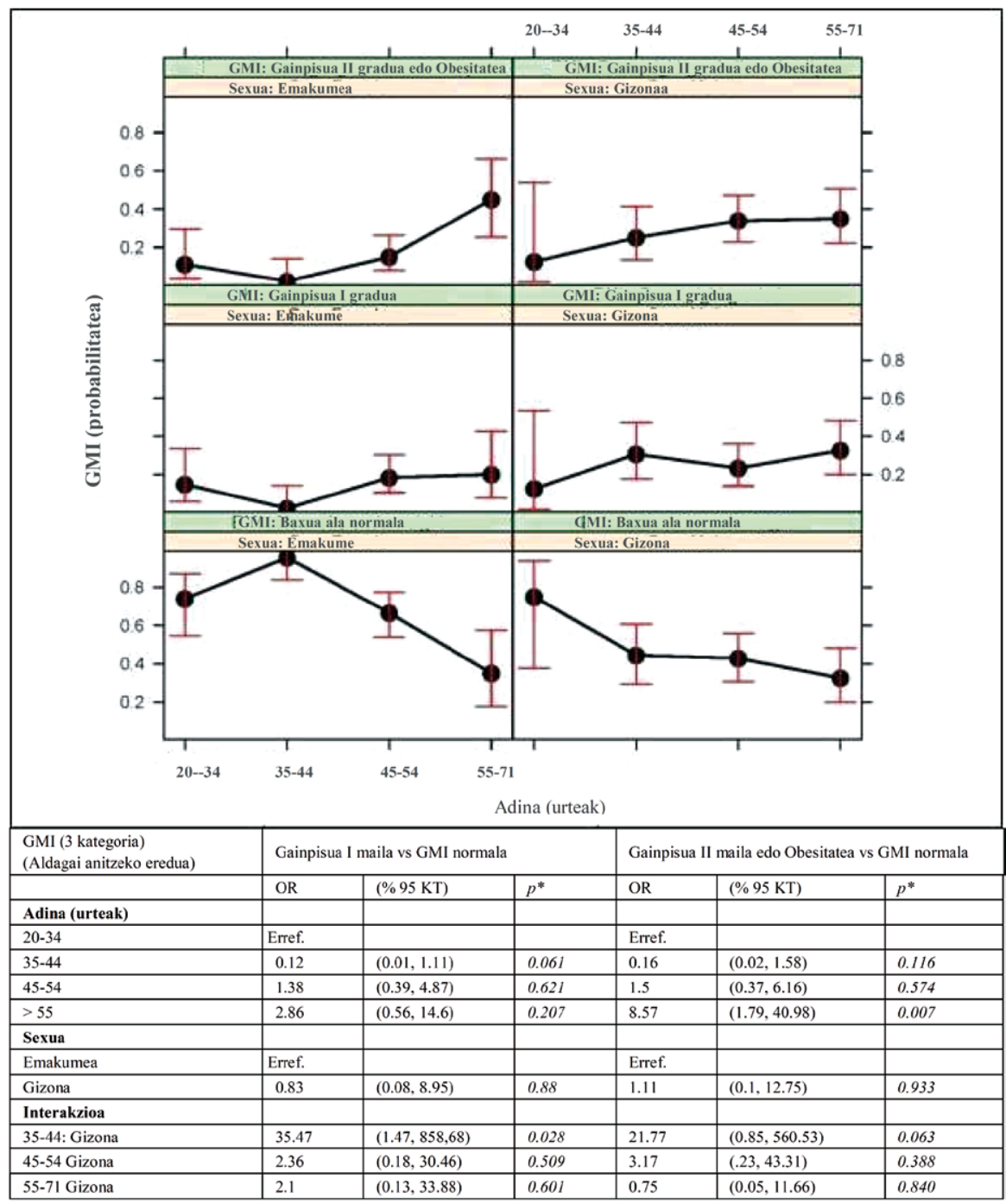

2. irudia. Esperotako probabilitatea GMIaren 3 kategorietako bakoitzean egoteko. Aldagai prediktiboak: sexua eta adina. * Wald-en testa erabili zen.

Aldagai anitzeko ingurunean gehiegizko pisuari eta obesitateari lotutako ezaugarriak 2. irudian ageri dira. I. mailako eta II. mailako gehiegizko pisuaren edo obesitatearen arriskua adinaren eta sexuaren araberakoa izan zen $(p<0,001)$. Oro har, gehiegizko pisua edo gizentasuna izateko arriskua handiagoa izan zen 45 urtetik gorako gizonezkoentzat bi sexuetako indibiduo gazteenentzat baino. Hala ere, sexuaren eta adinaren arteko eragin-tru- 
Itxazne Garcia-Ceciaga, Ana María Valle, Inmaculada Arostegui, Jaime Zubero, Begoña Marina Jugo, Elena Díaz-Ereño

kea estatistikoki esanguratsua izan zen ereduan $(p=0,006)$; beraz, emaitzak sexuaren arabera bereizi behar dira. 35 eta 44 urte bitarteko gizonek ia 30 aukera gehiago zituzten [KT \% $95(3,5,247,9)]$ I. mailako gehiegizko pisua izateko adin bereko emakumeek baino. Eta 35-44 urte bitarteko gizonek 24 aldiz baino probabilitate handiagoa zuten [KT \% 95 $(2,3,249,8)]$ II. mailako gainpisua izateko adin bereko emakumeek baino. 45 eta 54 urte bitarteko gizonek adin bereko emakumeek baino 3,5 aldiz probabilitate handiagoa zuten [KT \% $95(1,4,9,0)]$ II. mailako gainpisua edo obesitatea izateko.

Gizonen eta emakumeen arteko beste konparaketak ez ziren estatistikoki esanguratsuak izan. Adinaren araberako desberdintasunei dagokienez, $\geq 55$ urteko emakumeek 20 eta 34 urte bitarteko emakumeek baino arrisku handiagoa zuten II. mailako gehiegizko pisua edo obesitatea izateko $(\mathrm{OR}=8,6)$ [KT \% $95(1,8,41,0)]$. Beste adin-taldeentzako elkarteak ez ziren estatistikoki esanguratsuak izan emakumeentzat edo gizonentzat.

\section{EZTABAIDA}

Lan honek 292 unibertsitate-profesionalen datuak bildu eta erlazioak aztertu zituen gehiegizko pisuaren, obesitatearen, jarduera fisikoaren mailaren eta zenbait faktore soziodemografikoren, eguneroko ohituren eta unibertsitateko langileen lan-ezaugarrien artean, bai khi karratuaren froga erabilita, bai eta erregresio logistiko anizkoitza erabilita ere, jarduera fisikoaren zein GMIaren kasuan zentratuta aldagai prediktiboekin zein probabilitate duten kalkulaturik.

Lan-osasuneko azterketan datuak bildu ziren eta osagile kualifikatuek jasotako ohiko neurriez gaindi, neurri antropometriko osagarriak erabili ziren, azterlanaren datuak ahalik eta zehatzenak izateko. Gainera, partaideek bete zituzten auto-informatutako inkestek dietari, jarduera fisikoari, gizarte-, familia- eta lan-inguruneari buruz informazio zabala eman zuten. Haii lotutako galderak berariaz egokitu ziren ikerketa honetarako, testuinguru sozioekonomiko eta kultural berean baliozkotutako galdetegi bat erreferentziatzat hartuta.

Datuen bilketaren barnean, azpimarratzekoa da unibertsitateko langile boluntarioek bakarrik parte hartu izana; oro har, populazio orokorrak baino sentikortasun handiagoa izan zezaketen azpitalde batek osa dezake lagina, osasuna zaintzeko bai eta erraztasun gehiago osasun-zerbitzuetara eta hezkuntza-baliabideetara sarbidea izateko ere.

Bildutako datuei erreparatuz, gure lanean gehiegizko pisuaren eta obesitatearen prebalentzia konbinatua (\% 42) mundu-mailako [29] zein Espainiako erkidegoetako [30] populazio orokorrarena baino zertxobait txikia- 
goa izan zen. Langileen ikuspegitik ere, Espainiako milioi bat langile baino gehiagorekin egin zen ICARIA ikerlana eredutzat hartuta, gehiegizko pisuaren eta obesitatearen besteko prebalentzia \% 53,8koa aurkitu zen, eta antzera, Gelpi et al.-k argitaratutako lanean (2011) [7] Espainian pisu-gainkarga (gehiegizko pisua eta obesitatea) \% 57,5ekoa izan zen, eta Espainiar estatuko erkidego guztietan langile aktiboen $\%$ 50ek baino gehiagok obesitatea edo gehiegizko pisua zuten. Lan horren arabera, EAEn ehunekoa $\%$ 55ekoa izan zen. Beraz, unibertsitateko langile-kolektiboan prebalentzia-tasak 10 puntu inguru txikiagoak izan ziren [8].

Obesitate-prebalentzia baxuago hori azaltzeko aldagaien artean, maila sozioekonomiko eta hezkuntza-maila altuagoa izatea eta lan mota ditugu, beste eragile batzuen artean. Hezkuntza-mailak eragina du obesitatearen eta gehiegizko pisuaren garapenean [20], eta lan askotan maiz aurkitzen da lan-egoera eta diru-sarrerak ez ezik, hezkuntza maila ere erabili dela ikasitako biztanleen egoera sozio-ekonomikoaren adierazle gisa. Lan motari dagokionez, ICARIA ikerlanean eskuzko langileen obesitate-tasak langile intelektualenak baino altuagoak zirela ere ikusi zuten [8]. Portzentaje handienean langile intelektualek osatutako kolektiboa izanik, emaitza horrek ere azaldu lezake, hein batean bederen, gure laginean obesitate-prebalentzia txikiagoa izatea.

Emakumeak eta gizonak alderatzean, obesitatearen prebalentzia handiagoa izan zen gizonen artean. Emaitza hori bat dator espainiar estatuko bai langile-populazioaren [8] eta bai biztanleria orokorraren zenbait ikerketarekin $[20,30]$.

Adinarekin ere gainpisua zein obesitatea handitzen direla atzeman dugu. Beste ikerketa batzuen arabera, bi sexuetan handitzen da pisu-arazoen arriskua adina handitu ahala $[18,19]$. Halaber, gizonezkoak gehiegizko pisua edota obesitatea adin gazteenen taldean jasaten hasten direla ikusi dugu gure lanean. Emakumezko langileek, aldiz, pisuari eusteko joera dute, adin kritiko jakinera heldu arte (55 urte inguru), eta adin horretan, prebalentzia-tasak berdinak izan ziren bi sexuetan. Adin kritiko hori bat dator menopausiako [31] batez besteko adinarekin. Jakina da etapa horretan emakumeen pisua azkar handitzen dela, eta haien jarduera fisikoak behera egiten duela, eta, ondorioz, metabolikoki energia gutxiago erabiltzen dela [31].

Jarduera fisikoari dagokionez, OMEk emandako gomendioen betetzemaila handiagoa izan zen parte-hartzaileetan Espainiako biztanleria orokorrarekin [32-34] zein Espainiako biztanleria aktiboarekin [13] alderatuz. Ikerlan horietan IPAQ eta haren antzeko galdetegiak erabili ziren; IPAQ galdetegia da, gaur egun, jarduera fisikoa ebaluatzeko tresnarik egingarriena eta eskuragarriena [32], bai eta erabilienen artean dagoen metodologia ere [33]; baina jardueraren gomendioak betetzen dituzten subjektuen 
Itxazne Garcia-Ceciaga, Ana María Valle, Inmaculada Arostegui, Jaime Zubero, Begoña Marina Jugo, Elena Díaz-Ereño

ehunekoa handiagoa izan liteke gure emaitzetan neurketa metodo objektiboen bidez lortutako emaitzekin alderatuko balitz, hala nola podometroekin edo azelerometroekin; auto-informatua denez, alde batetik oroimenaren alborapena komuna duelako, eta erantzun ez-osatuak azaldu ditzake, eta bestetik gainestimazio-joera daukalako [35].

Obesitatearen edota gehiegizko pisuaren eta jarduera fisikoaren arteko alderantzizko erlazioa ongi ezarrita dago. Hala ere, ANIBES (Anthropometry, Intake and Energy Balance in Spain) ikerketak ondorioztatu zuen jarduera-mailak eragina izan zuela obesitatearen prebalentzian; beraz, jarduera fisiko kementsuari eskainitako denbora luzeagoa, baina ez intentsitate ertaineko jarduera fisikoari, obesitate orokor eta obesitate abdominalaren arrisku txikiagoekin lotu zen [20]. Azterlan honetan ez dugu ikusi jarduera fisikoaren mailaren edo GMIren balioen arteko loturarik, Varo et al.-k (2003) [36] edota Dugas et al.-k (2014) [37] ikusi bezala. Agian, lagin handiago eta heterogeneoago batek azalduko luke hobeto eragin-truke hori.

Obesitatea, familia-egitura, lan-orduak eta bizimoduaren arrisku-faktoreak atzemateko aztertu ziren. Loaldiaren iraupena obesitateari eta jarduera fisikoari lotutako faktore gisa agertu zen. Azken urteetako ikerketa epidemiologikoen arabera, loaldi laburra obesitatearen garapenari lotuta egon daiteke $[9,22]$, eta horietako batzuek harremana behatu zuten obesitatea gerriaren zirkunferentziaren arabera ebaluatu zenean, eta ez GMIaren arabera ezartzean [22].

Gure emaitzen arabera, loaren iraupen laburra ( $<7$ ordu/egun) gehiegizko pisua eta obesitatea izateko arrisku handiagoari lotu zitzaien, partehartzaileak bi kategoriatan sailkatu zirenean GMI (pisu normala vs gehiegizko pisua/obesitatea) $(p=0,021)$. Erlazio hori ez zen esanguratsua izan hiru kategorien sailkapenean, lagin-tamaina mugatuagatik agian. Aurkikuntza hori bat dator aurretiko Espainia mailako [20,38], Europa mailako [39], eta langileen arteko [21] ikerlanekin. Pisuaren eta loaren iraupenaren arteko erlazioa adinaren eta sexuaren arabera doitu zenean, ez zen estatistikoki esanguratsua izan, iradokiz erlazio esanguratsua adinaren eta sexuaren arabera nahastu zela.

Harrigarria bada ere, lan honetan jarduera fisikoak loaren iraupenarekin ere zerikusia izan zuen. Aldagai anitzeko analisiaren arabera, gomendioekiko atxikidura-maila handiagoa izan zen loaren iraupen laburragoarekin ( $<7$ ordu/egun). Jarduera fisikoaren egokitze-iragarletzat har daiteke. Hala ere, diseinua dela eta, ezin da zehaztu loaren iraupenaren eta jarduera fisikoaren arteko erlazioaren noranzkoa. Adibidez, St-Onge et al.-ren arabera (2016) [2] lo laburreko azpitalde batzuk fisikoki aktiboagoak izatea denbora luzeagoz esna egotearen ondorioz litzateke, eta gaizki lo egiten duten beste batzuek, berriz, energia gutxiago eta aktibatzeko gaitasun gutxiago izateagatik [2]. 
Loaren kalitatearen eta jarduera fisikoaren arteko erlazioa [40] aldez aurretik karakterizatu da. Hala ere, ikerketa gutxik hartu dute gaueko atseden-denbora jarduera fisikoari lotutako faktoretzat. Autore batzuen emaitzak bat datoz gureekin; Lambiase et al.-k (2013) [41] ikusi zuten eguneko jarduera fisikoa gaueko atsedenaldi gutxiagorekin erlazionatu zela. Azterlan gehiago behar dira aurkikuntza hori baieztatzeko eta eragin-truke horren norabidea hobeto ulertzeko.

Sexu eta adin desberdineko unibertsitateko bi kolektiboren gehiegizko pisuaren eta obesitatearen prebalentziari buruzko informazio espezifikoa ematen du gure ikerketak. Gainera, ezaugarri soziodemografiko eta bizi-estilo desberdinek indibiduo horiek bizi eta lan egiten duten ingurunea deskribatzen dute, eta osasuna sustatzeko estrategiak pertsonalizatzen lagunduko duten jokabide-profilak nabarmentzen dituzte.

\section{ONDORIOAK}

Unibertsitateko langileen gehiegizko pisuaren eta obesitatearen arteko konbinazioa biztanleria orokorrarena baino txikiagoa izan zen, nahiz eta $\%$ 40tik gorako balioa hartu. Gizonetan handiagoa izan zen, eta bi sexuetan adinean aurrera egin ahala handitu egin zen, bereziki 55 urtetik gorako emakumeen artean eta 35 urtetik gorako gizonen artean. Beraz, gomendagarria dirudi laneko osasuna zaintzeko protokoloetan pisuaren kontrola mantentzea, bereziki sexu bakoitzerako ikusitako adin kritikoentzat. Jarduera fisikoaren IPAQ-aren sailkapenaren barnean oso aktiboak ziren profesionalen ehunekoa txikia izan zen, ia $\% 25$, baina ia langile guztiek bete zituzten OMEren gomendioak. Gainera, gaueko loa jarduera fisikoaren egokitzapenarekin erlazionatu zen, eta binomio hori behatzeko beharra adierazten du, bai eta gorputz-pisuarekin izan zezakeen interakzioa ere.

\section{ESKER ONAK}

Eskerrak eman nahi dizkiegu lan honetan parte hartu duten guztiei, egindako ahaleginagatik eta eskuzabaltasunagatik, eta UPV/EHUko Prebentzio Zerbitzuari, batez ere, Iñigo Apellaniz, Iñaki Uruburu medikuei eta Miren Muxika erizainari beren lankidetza bikainagatik. Itxazne Garcia-Ceciagari hein batean lagundu zion UPV/EHUko Berdintasunerako Zuzendaritzaren unibertsitate-beka batek, emakumeen eta gizonen arteko berdintasunari laguntzen dioten ikerketa zientifikoak egiteko. Lan hau Euskal Herriko Unibertsitateak (UPV/EHU) finantzatu du (Begoña Jugori emandako GIU10/22, eta UFI 11/20 diru-laguntzen bidez). Inmaculada Arostegui doktorearen ikerketa Eusko Jaurlaritzako Hezkuntza, Hizkuntza Politika eta Kultura Sailak finantzatu du (IT62013). 
Itxazne Garcia-Ceciaga, Ana María Valle, Inmaculada Arostegui, Jaime Zubero, Begoña Marina Jugo, Elena Díaz-Ereño

\section{BIBLIOGRAFIA}

[1] Buorvatn, B., Sagen, I. M., Øyane, N., Waage, S., Fetveit, A., Pallesen, S., URSIN, R. 2007. "The association between sleep duration, body mass index and metabolic measures in the Hordaland Health Study». Journal of Sleep Research, 16, 66-76.

[2] St-Onge, M. P., Grandner, M. A., Brown, D., Conroy, M. B., JeanLouis, G., Coons, M., BhAtт, D. L. 2016. «Sleep Duration and Quality: Impact on Lifestyle Behaviors and Cardiometabolic Health: A Scientific Statement from the American Heart Association». Circulation, 134, e367-e386.

[3] World Health Organization (WHO). 2007. Global Plan of Action on Workers' Health 2008-2017. Resolution WHA60.26. Geneva, Switzerland.

[4] Masanotti, G. 2014. "The worksite as an asset for promoting health in Europe. Final results of the MoveEurope campaign.». Igiene e sanità pubblica, 70, 185-196.

[5] Florindo, A. A., Brownson, R. C., Mielke, G. I., Gomes, G. A., Parra, D. C., Siqueira, F. V., Lobelo, F., Simoes, E. J., Ramos, L. R., Bracco, M. M., Hallal, P. C. 2015. «Association of knowledge, preventive counseling and personal health behaviors on physical activity and consumption of fruits or vegetables in community health workers Health behavior, health promotion and society». BMC Public Health, 15, 1-8.

[6] WHO. 2004. Global Strategy on Diet, Physical Activity and Health. Geneva, Switzerland.

[7] Gelpi Méndez, J. A., Martín Barallat, J., Cortés Arcas, M. V., Calvo Mora, A., Romero Mateos, I., Arauzo Esteban, S. 2011. «Prevalencia de peso insuficiente, sobrepeso y obesidad en población laboral activa española». Archivos de prevención de riesgos laborales, 14, 80-87.

[8] Goday-arnó, A., Calvo-bonacho, E., Sánchez-Chaparro, M.-Ángel. 2013. «High prevalence of obesity in a Spanish working population». Endocrinología y nutrición, 60, 173-178.

[9] Amani, R., Gill, T. 2013. «Shiftworking, nutrition and obesity: Implications for workforce health-A systematic review». Asia Pacific Journal of Clinical Nutrition, 22, 698-708.

[10] Cash, S. W., Beresford, S. A. A., Henderson, J. A., McTiernan, A., Xiao, L., WANG, C. Y., PAtRICK, D. L. 2012. «Dietary and physical activity behaviours related to obesity-specific quality of life and work productivity: Baseline results from a worksite trial». British Journal of Nutrition, 108, 1134-1142.

[11] Verweis, L. M., Coffeng, J., van Mechelen, W., Proper, K. I. 2011. «Meta-analyses of workplace physical activity and dietary behaviour interventions on weight outcomes». Obesity Reviews, 12, 406-429.

[12] Warburton, D. E. R., Charlesworth, S., Ivey, A., Nettlefold, L., BreDIN, S. S. D. 2010. «A systematic review of the evidence for Canada's Physical Activity Guidelines for Adults». International Journal of Behavioral Nutrition and Physical Activity, 7, 39. 
[13] Moreno-Franco, B., Peñalvo, J. L., Casasnovas Lenguas, J. A., LeonLATRE, M. 2015. «Factores asociados al cumplimiento de las recomendaciones sobre actividad física en población trabajadora de entre 40 y 55 años de edad». Revista Española de Salud Pública, 89, 447-457.

[14] Pedersen, B. K., Saltin, B. 2015. «Exercise as medicine - Evidence for prescribing exercise as therapy in 26 different chronic diseases». Scandinavian Journal of Medicine and Science in Sports, 25, 1-72.

[15] World Health Organization (WHO). 2009. Global Health Risks : Mortality and Burden of Disease Attributable to Selected Major Risks. World Health Organization, Geneva, Switzerland.

[16] WHO EUROPE, CAvill, N. 2006. Physical Activity and Health in Europe: Evidence for Action. World Health Organization (WHO), Copenhagen, Denmark.

[17] Young, D. R., Hivert, M. F., Alhassan, S., Camhi, S. M., Ferguson, J. F., Katzmarzyk, P. T., Lewis, C. E., Owen, N., Perry, C. K., Siddique, J., YonG, C. M. 2016. «Sedentary behavior and cardiovascular morbidity and mortality: A science advisory from the American Heart Association». Circulation, 134, e262-e279.

[18] Dohk, C. M., Wijnhoven, T. M. A., Schokker, D. F., Visscher, T. L. S., SEIDELL, J. C. 2012. «Age standardization in mapping adult overweight and obesity trends in the WHO European Region». Obesity Reviews, 13, 174191.

[19] Ortega Anta, R. M., López-Sobaler, A. M., Pérez-Farinós, N. 2013. «Associated factors of obesity in Spanish representative samples». Nutricion Hospitalaria, 28, 56-62.

[20] López-Sobaler, A. M., Rodríguez-Rodríguez, E., Aranceta-Bartrina, J., Gil, Á., Gonzalez-Gross, M., Serra-Majem, L., Varela-Moreiras, G., ORTEGA, R. M. 2016. «General and abdominal obesity is related to physical activity, smoking and sleeping behaviours and mediated by the educational level: Findings from the ANIBES study in Spain». PLoS ONE, 11, DOI: 10.1371/journal.pone.0169027.

[21] Di Milia, L., Mummery, K. 2009. «The association between job related factors, short sleep and obesity». Industrial Health, 47, 363-368.

[22] Elder, B. L., Ammar, E. M., Pile, D. 2016. «Sleep Duration, Activity Levels, and Measures of Obesity in Adults». Public Health Nursing, 33, 200-205.

[23] López-Sobaler, A. M., Rodríguez-Rodríguez, E., Aranceta-Bartrina, J., Gil, Á., Gonzalez-Gross, M., Serra-Majem, L., Varela-Moreiras, G., ORTEGA, R. M. 2016. «General and abdominal obesity is related to physical activity, smoking and sleeping behaviours and mediated by the educational level: Findings from the ANIBES study in Spain». PLoS ONE, 11, 1-13.

[24] Salas-Salvadó, J., Rubio, M. A., Barbany, M., Moreno, B. 2007. «Consenso SEEDO 2007 para la evaluación del sobrepeso y la obesidad y el establecimiento de criterios de intervención terapéutica». Medicina clinica, 128, 184-196. 
Itxazne Garcia-Ceciaga, Ana María Valle, Inmaculada Arostegui, Jaime Zubero, Begoña Marina Jugo, Elena Díaz-Ereño

[25] Roman-Viñas, B., Serra-Majem, L., Hagströmer, M., Ribas-Barba, L., SJÖStröm, M., SEgURA-CARdONA, R. 2010. «International physical activity questionnaire: Reliability and validity in a Spanish population». European Journal of Sport Science, 10, 297-304.

[26] Ainsworth, B. E., Haskell, W. L., Whitt, M. C., Irwin, M. L., Swartz, A. M., Strath, S. J., O’Brien, W. L., Bassett, D. R. J., Schmitz, K. H., Emplaincourt, P. O., Jacobs, D. R. J., LeOn, A. S. 2000. «Compendium of physical activities: an update of activity codes and MET intensities.». Medicine and science in sports and exercise, 32, S498-504.

[27] Patterson, E. 2010. Guidelines for Data Processing and Activity Analysis of the International Physical Activity Questionnaire (IPAQ) - Short and Long Forms.

[28] WHO. 2010. Global Recommendations on Physical Activity for Health. Geneva, Switzerland.

[29] World Health Organization (WHO)The Global Health Observatory. Explore a world of health data, http://www.who.int/gho/ncd/risk_factors/ overweight/en/ (last time accessed: June 28, 2021).

[30] Aranceta-Bartrina, J., Pérez-Rodrigo, C., Alberdi-Aresti, G., RamosCARrera, N., LÁZARo-Masedo, S. 2016. «Prevalencia de obesidad general y obesidad abdominal en la población adulta española (25-64 años) 20142015: estudio ENPE». Revista Espanola de Cardiologia, 69, 579-587.

[31] Proietto, J. 2017. «Obesity and weight management at menopause». Australian Family Physician, 46, 368-370.

[32] Guthold, R., Ono, T., Strong, K. L., Chatterji, S., Morabia, A. 2008. «Worldwide Variability in Physical Inactivity. A 51-Country Survey». American Journal of Preventive Medicine, 34, 486-494.

[33] Loyen, A., Van Hecke, L., Verloigne, M., Hendriksen, I., Lakerveld, J., Steene-Johannessen, J., Vuillemin, A., Koster, A., Donnelly, A., EkeLund, U., Deforche, B., De Bourdeaudhui, I., Brug, J., VAn Der Ploeg, H. P. 2016. «Variation in population levels of physical activity in European adults according to cross-European studies: A systematic literature review within DEDIPAC». International Journal of Behavioral Nutrition and Physical Activity, 13, DOI: 10.1186/s12966-016-0398-2.

[34] Pérez-Rodrigo, C., Gianzo-Citores, M., Gil, Á., González-Gross, M., Ortega, R. M., Serra-Majem, L., Varela-Moreiras, G., Aranceta-BarTRINA, J. 2017. «Lifestyle patterns and weight status in Spanish adults: The ANIBES study». Nutrients, 9, DOI: 10.3390/nu9060606.

[35] Lee, P. H., Macfarlane, D. J., Lam, T. H., Stewart, S. M. 2011. «Validity of the international physical activity questionnaire short form (IPAQ-SF): A systematic review». International Journal of Behavioral Nutrition and Physical Activity, 8, 115.

[36] Varo, J. J., Martínez-González, M. A., de Irala-Estévez, J., Kearney, J., Gibney, M., Martínez, J. A. 2003. «Distribution and determinants of se- 
dentary lifestyle in the European Union». International Journal of Epidemiology, 32, 138-146.

[37] Dugas, L. R., Bovet, P., Forrester, T. E., Lambert, E. V., Plange-Rhule, J., Durazo-Arvizu, R. A., Shoham, D., Kroff, J., CaO, G., Cooper, R. S., Brage, S., EkElund, U., LuKE, A. 2014. «Comparisons of intensity-duration patterns of physical activity in the US, Jamaica and 3 African countries». BMC Public Health, 14, DOI: 10.1186/1471-2458-14-882.

[38] Sayón-Orea, C., Bes-Rastrollo, M., Carlos, S., Beunza, J. J., BasterraGortari, F. J., MartínEZ-GonzÁLEZ, M. A. 2013. «Association between Sleeping Hours and Siesta and the Risk of Obesity: The SUN Mediterranean Cohort». Obesity Facts, 6, 337-347.

[39] Lyytikäinen, P., Rahkonen, O., Lahelma, E., LallukKa, T. 2011. «Association of sleep duration with weight and weight gain: A prospective follow-up study». Journal of Sleep Research, 20, 298-302.

[40] Yang, P.-Y., Ho, K.-H., CHEN, H.-C., CHIEn, M.-Y. 2012. «Exercise training improves sleep quality in middle-aged and older adults with sleep problems: a systematic review.». Journal of physiotherapy, 58, 157-163.

[41] Lambiase, M. J., Gabriel, K. P., Kuller, L. H., Matthews, K. A. 2013. «Temporal relationships between physical activity and sleep in older women». Medicine and science in sports and exercise, 45, DOI: 10.1249/ MSS.0b013e31829e4cea. 